\title{
Tantangan Dunia Pesantren Era Milenial
}

\author{
${ }^{1}$ Muhammad Zul Fadli, ${ }^{2}$ Imam Syafii \\ ${ }^{12}$ UIN Sunan Ampel Surabaya \\ Email: Pondoktremas0@,gmail.com
}

\begin{abstract}
Islamic boarding schools are a noble legacy of Islamic teachers and values in the archipelago. The treasures of Indonesian Islamic culture must be preserved and maintained so as not to lose their identity. Pesantren produced figures of freedom fighters, founders of the nation and many other vital roles that have been taken as a form of love for the nation and state. Recently, pesantren have experienced many challenges in line with the times that demand that pesantren must change and meet the community's educational needs. The problem of pesantren education is an exciting topic to study for reforming Islamic education in the future.
\end{abstract}

Keywords: Pesantren, Education, Problematics

\section{Pendahuluan}

Islam menjadikan pendidikan sebagai pendewasaan mental, moral dan akal dalam rangka menjadi manusia yang dapat menjadi manusia seutuhnya agar melaksanakan tugas yang dibawanya menjadi sosok hamba yang taat pada Tuhannya juga sebagai pemelihara alam semesta. Abdul Fattah Jalal mengatakan bahwa tujuan universal pendidikan Islam adalah menjadi manusia yang pantas disebut hamba Allah. ${ }^{1}$ Disimpulkan bahwa fungsi pendidikan yaitu guna mempersiapkan peserta didik dengan keahlian serta kemampuan yang dibutuhkan agar siap berbaur ditengah masyarakat dan menjadi manusia yang baik.

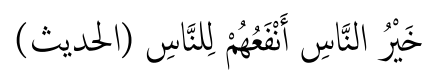

(Sebaik-baik manusia adalah yang bermanfaat bagi manusia lainnya). ${ }^{2}$

Lembaga Islam tertua di Indonesia yang memiliki banyak kontribusi turut serta mencerdaskan kehidupan bangsa yang masih eksis sampai saat ini adalah pesantren. ${ }^{3}$ Banyak perbedaan yang tersirat maupun tersurat pada pesantren dan lembaga pendidikan Islam formal. Pesantren identik dengan ketradisionalan sedangkan sekolah atau lembaga pendidikan Islam formal condong pada konsep kemoderenan pendidikan. Pesantren mempertahankan tradisi klasik dengan mengkultuskan barokah Kyai sedang sifat leberal sering ditekankan pada sekolah atau lembaga pendidikan Islam formal. Namun, persepsi dikotomi seperti ini sudah kurang relevan, karna banyak pesantren yang membuka diri untuk mengembangkan pola pendidikan dalam segala bidang. Pesantren bukan lagi berkutat pada kitab kuning saja, tetapi pesantren saat ini menjadi keunikan budaya yang berimplikasi sosial tinggi dalam kehidupannya.

\footnotetext{
${ }^{1}$ A. Tafsir, Imu Pendidikan Dalam Perspektif Islam, (Bandung: Remaja Rosdakarya, 2005), 57

${ }^{2}$ HR. Ahmad, At-Thabrani, Ad-Daruqutni dalam Shahihul Jami', No. 3289.

3 Ainur Rofieq, Profil Umum Beberapa Aspek Pendidikan Formal yang diselenggarakan Pesantren seKaresidenan Malang dalam Mendongkrak Mutu Pendidikan (Malang: FKIP Universitas Muhammadiyah Malang, 2004), 89
} 
Pedesaan menjadi basis terbesar kemunculan, berkembang dan tersebarnya pesantren di Indonesia. Nilai-nilai strategis pengembangan masyarakat Islam ala pesantren menambah estetika ke-khas-an pesantren sebagai lembaga pendidikan Islam tertua Indonesia. Kehidupan masyarakat muslim Indonesia banyak dipengaruhi dari pendidikan pesantren sehingga mudah tumbuh dan meluas penyebarannya diseluruh pelosok daerah nusantara.

Pada pendidikan nasional berdasar sejarah pertumbuhan dan perkembangan di Indonesia menyebutkan sumber minat masyarakat semakin banyak tertuju pada pesantren. Dikalangan umat Islam di Indonesia, pesantren menjadi pilihan institusi pendidikan yang memiliki nilai jual lebih, dilihat dari kebudayaan luhur keilmuan Salaffuna As-Sholih dan pengimplementasian nilai Islam yang rahmatan lilalamin pada setiap gerak hidupnya. Pesantren seolah tiada pembatas bagi siapa saja yang ingin datang padanya dan mampu digapai seluruh lapisan masyarakat tanpa terkecuali. ${ }^{4}$

Pembenahan yang dilakukan pesantren karna tuntutan zaman berbuah problematika yang kompleks. Peran penting pesantren sebagai peyi'ar ajaran agama dan penerjemahnya kepada masyarakat luas serta mempertahankan identitasnya atas label lembaga pendidikan asli Indonesia, pesantren melakukan filterisasi agar budaya yang ada tidak tercemari dengan istilah kekinian yang malah melemahkan posisi pesantren itu sendiri. Konsep yang selalu dipegang pesantren dalam pengembangan pendidikannya adalah

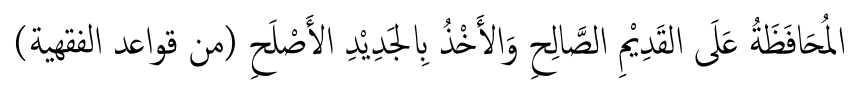

(menjaga tradisi-tradisi lama yang baik dan mengambil tradisi-tradisi modérn yang lebih baik). ${ }^{5}$

\section{Metode Penelitian}

Pembahasan dalam penulisan ini menggunakan pendekatan metode kuantitatif dengan jenis penelitian kepustakaan. Pencarian data dan observasi dilakukan dalam rangka menganalisis sumber data agar dijasikan dalam bentuk laporan penelitian kepustakaan. Sumber kajian berasal dari buku-buku dan jurnal-jurnal yang relevan agar menunjang keabsahan data, pengkajian dimulai dari topik yang umum kepada topik yang spesifik.

\section{Pembahasan}

\section{A. Pesantren Era Milenial}

Islam merupakan suatu agama yang memiliki kesempurnaan dan komperhensif dibanding agama lainnya. ${ }^{6}$ Islam adalah agama yang menjadi pedoman hidup manusia karna keluhuran ajaran nilai yang diajarkan sampai

\footnotetext{
${ }_{4}$ M. Rahardjo, Ed. Quo Vadis Pendidikan Islam: Membaca Realitas PendidikanIslam, Sosial dan Keagamaan..(Malang: UIN Malang Press, 2006), 8

${ }^{5}$ Jalaludin As-Suyuthi, Al-Asybah wa An-Nadzoir, (Jakarta: Darul Kutub Ilmiah, 2005), 125

${ }^{6}$ Samsudin, Integrasi Tri Pusat Pendidikan dalam Pendidikan Agama Islam, Al-Murabbi: Jurnal Studi Kependidikan dan Keislaman, Vol. 5 (02). 219
} 
akhir zaman. ${ }^{7}$ Nilai yang terkandung didalam ajaran agama dapat diserap melalui pendidikan. Mustahil pemahaman akan nilai ajaran agama didapat dari warisan tanpa adanya pendidikan. Fokus ajaran agama lebih menjurus pada budi pekerti dan nilai luhur kehidupan manusia yang diimplementasikan berdasar dalil agama yang termaktub dalam catatan kitab suci yang disebut al-Quran.

Zakiah Darajat menuturkan bahwa pendidikan Islam merupakan pendidikan yang lebih banyak ditujukan guna perbaikan sikap mental yang akan terwujud dalam perbuatan, baik keperluan diri sendiri maupun orang lain yang bersifat teoritis dan praktis. ${ }^{8}$ Terlalu banyak problem pada pendidikan Indonesia, mulai dari level atas sampai ke level dasar. Permasalahan di level atas yakni tumpang tindihnya aturan yang mengikat dan tidak efektif bagi pembelajaran, tak jarang sekolah yang berada pada daerah 3T sulit mengikuti regulasi yang berlaku. Pada level dasar permasalahan dirasakan sekolah-sekolah paling banyak pada bidang infrastruktur, gaji guru dan kurikulum. Belum lagi masalah yang menghantui para peserta didik baik didalam ataupun luar sekolah.

Indonesia adalah negara dengan mayoritas muslim terbesar yang ada sampai pelosok daerah. Pada realitanya, pendidikan Islam tidak menjadi mayoritas dalam pendidikan nasional. Pendidikan Islam acapkali dipandang sebelah mata pada pendidikan nasional, bahkan sering dimarginalkan. Nyatanya, bagaimanapun jenis pendidikannya, semua pendidikan hakikatnya adalah mengembangkan harkat dan martabat manusia menjadi lebih baik.

Sistem pendidikan nasional memandang adanya pendidikan Islam pada tiga jenis yang utama. ${ }^{9}$ 1) Pendidikan Islam dipandang sebagai lembaga pendidikan yang nyata dengan bentuk sekolah formal Islam dan pesantren. 2) Pendidikan Islam dipandang sebagai mata pelajaran yang diwajibkan mulai jenjang sekolah dasar sampai dengan sekolah lanjutan atau perguruan tinggi. 3) Pendidikan Islam dipandang sebagai nilai yang muncul dalam sistem pendidikan yang berlaku. Pendidikan Islam bisa masuk pada setiap lini sistem pendidikan yang ada, minimal berlaku sebagai nilai

Pesantren bisa dikatakan sempurna jika memiliki rukun utama. ${ }^{10}$ 1) Kyai, Tuan Guru, Anre Gurutta, Inyaik, Syekh, Ajengan, Buya, Nyai, atau sebutan lain yang kemudian disebut Kyai merupakan sosok pendidik yang memiliki kompegensi ilmu agama Islam yang memiliki peran sebagai tauladan dan pengasuh pesantren. 2) Santri yang mukim menempuh pendidikan agama Islam dibawah asuhan Kyai sepanjang waktu. 3) Pondok atau asrama merupakan tempat tinggal dan belajar santri selama melakukan proses pendidikan di pesantren. 4) Masjid selain tempat melakukan shalat berjama'ah, dzikir dan istighosah, masjid juga difungsikan sebagai pusat pendidikan pembelajaran keagamaan yang dilakukan oleh Kyai. 5) Kajian kitab kuning sebagai kitab

\footnotetext{
7 Suyudi, Filsafat Pendidikan Islam dalam Kajian Filosofis dan Pemikiran Pendidikan Islam, (Yogyakarta: Belukar, 2014), 5

${ }^{8}$ Zakiah Darajat, Pendidikan Islam dalam Keluarga dan Sekolah, (Jakarta: Ruhama, 2006), 25

${ }^{9}$ Ibid, 28

10 Wahyu Iryana, Tantangan Pesantren Salaf di Era Modern, Al-Murabbi, Vol. 2 (01) 2015, 70
} 
rujukan dalam seluruh pembelajarannya. Kitab yang diajarkan mayoritas berbahasa arab walau ada beberapa yang menggunakan terjemahan, kitab berbahasa melayu atau berbahasa jawa dan lainnya. ${ }^{11}$

Idealnya pesantren memiliki dua fungsi utama yakni pelestarian nilai-nilai etik dan mobilitas sosial serta pengembangan intelektual tradisional. Pesantren memposisikan pendidikan menjadi media yang mampu memobilitas masyarakat agar berkehidupan atas dasar-dasar nilai Islam yang kaffah. Pesantren memposisikan diri sebagai pengembang nilai dan ajaran agama Islam sehingga terwujud masyarakat yang madani bukan hanya mempertahankan tradisi dan mampu memobilisasi kekuatan umat. Pengembangan intelektual menjadi domain yang sangat penting dilakukan pesantren berlandas nilai luhur agama sehingga terbentuk insan kamil sebagai pioner kedamaian dan persatuan bangsa.

Pesantren lahir dan berkembang sesuai perubahan di masyarakat. Sub kultur masyarakat turut mewarnai setiap inovasi yang dilakukan pesantren secara umum. Oleh sebab itu, setidaknya ada dua potensi utama dari pesantren yang dapat dikembangkan, yaitu pengembangan pendidikan dan pengembangan masyarakat sekaligus. Pesantren menjadi institusi pendidikan yang unik jika dilihat keberadaannya belakangan ini karna lebih banyak mempertahankan konsep ketradisionalan dan perannya yang eksistensinya dalam membina umat.

Internalisasi nilai ajaran Islam yang digelorakan pesantren berhasil dilakukan pada masyarakat. Pembentukan masyarakat yang dilakukan pesantren menghendaki terwujudnya masyarakat Islam yang bubbul wathan, komperhensif dan semangat dalam melakukan transformasi peradaban uang madani. Hal ini menjadi dasar dari peran pendidikan Islam dari sisi lembaga pendidikan Islam.

Jauh sebelum kolonialisme hadir di bumi Nusantara, sesungguhnya pendidikan di bumi khatulistiwa ini sudah sangat maju, meskipun belum terlembagakan. Namun untuk ukuran zaman masa itu pendidikan ala orangorang Nusantara sudah terbilang sangat maju. Pendidikan yang berorientasi pada pengajaran dan penanaman nilai-nilai keagamaan tersebut kemudian hari oleh para peneliti disebut dan dinamakan pondok pesantren. ${ }^{12}$

\section{B. Jenis- Jenis Pesantren}

Wahyu Iryana mengutip penjelasan Nurcholis Majid (1997) bahwa pesantren di Indonesia terbagi menjadi empat jenis dilihat dari perkembangan laju arus modernisasi. ${ }^{13}$ 1) Pesantren yang semangat memodernisasi segala unsur kelembagaannnya, jenis ini sangat kompatibel dalam kesemangatan berkemajuan. 2) Pesantren yang menerima modernisasi dalam sebagian aspek kelembagaan dan tetap mempertahankan keunggulan tradisi citra lembaga. 3) Pesantren yang menyadari perlunya modernisasi dalam pola pendidikannya tetapi tetap menahan

\footnotetext{
11 Moh Toriqul Chaer, "Pesantren: Antara Transformasi Sosial Dan Upaya Kebangkitan Intelektualisme Islam," FIKRAH 5, no. 1 (June 22, 2017): 49-74, https://doi.org/10.21043/fikrah.v5i1.2145.

${ }^{12}$ Ibid, 28

13 Wahyu Iryana, Tantangan ....................,72
} 
diri untuk menjadi pilar penjaga tradisionalisme. 4) Pesantren yang menolak terhadap segala bentuk modernisasi dan bertahan dengan kesalafan pesantrennya. Amin (2012) mengelompokkan pesantren menjadi dua jenis, pesantren ashriyah dan salafiyah. ${ }^{14}$ Pesantren jenis ashriyah yang belakangan disebut pesantren modern adalah pesantren yang mendirikan sekolah formal dalam institusinya sedang pesantren jenis salafiyah yang belakangan disebut pesantren kampung atau desa merupakan pesantren yang tidak memiliki lembaga formal.

Berdasar dua pengelompokan diatas, secara garis besar pesantren terbagi menjadi tiga kelompok besar. 1) Pesantren salaf yakni pesantren yang memiliki ciri khas mempertahankan pengajian kitab kuning sebagai materi pokok tanpa mengajarkan pendidikan umum. Metode pengajaran masih menggunakan metode sorogan, setoran, bandongan dan wetonan serta menjadikan masjid sebagai sarana utama pendidikan. Santri tidak dibuat perkelas sesuai jenjang usia tapi lebih sesuai kemampuan penguasaan materi kajian dan santri tidak begitu mengharapkan adanya ijazah sebagai legalitas pendidikan selama pembelajaran. 2) Pesantren khalaf menerapkan model klasikal, kurikulum dan mata pelajaran yang dipadukan dengan pelajaran umum atau kurikulum nasional. Jenjang pendidikan disesuaikan dengan usia dan dibatasi waktu serta para santri memiliki ijazah untuk melanjutkan ke ejnjang pendidikan selanjunya. 3) Perpaduan pesantren salaf dan khalaf yakni jenis pesantren yang memadukan antara kekentalan pendidikan tradisional dengan pendidikan modern yang disesuaikan dengan tuntunan zaman. Santri tetap memiliki value keagamaan disertai sikap moderat yang tinggi.

\section{Problematika Pesantren Era Milenial}

Seiring perkembangan zaman, problem yang dihadapi oleh pesantren semakin kompleks. Pesantren dituntut untuk bersaing dengan lembaga pendidikan umum yang lebih modern. Indonesia memiliki jumlah pesantren yang meningkat signifikan setiap masanya. Sayangnya, pertambahan jumlah tersebut tidak diiringi dengan peningkatan kualitas dan mutu pesantren. Bahkan pendidikan di pesantren mengalami kemerosotan yang tajam. Hal ini disebabkan banyak pesantren khususnya pesantren modern lebih mengutamakan pendidikan formalnya dari pada pendidikan diniyahnya. Jangan heran jika ada santri yang mondok tiga sampai enam tahun tetapi tidak bisa membaca kitab. Meskipun demikian, tidak semua pesantren modern mengedepankan pendidikan formalnya dari pada pendidikan diniyahnya.

Indonesia memiliki dua jenis pesantren berdasarkan kurikulum yang digunakan dalam proses pendidikannya. ${ }^{15}$ Pesantren salafiyah (tradisional) yang dengan kukuh mempertahankan tradisi klasiknya dalam mengembangkan kurikulum dengan menggunakan kitab-kitab kuning sebagai rujukan utama dan pesantren ashriyah (modern) yang merujuk pada standar kurikulum nasional yang

14 Ibid, 72.

15 M. B. Ghazali, Pendidikan Pesantren Berwawasan Lingkungan: Kasus Pondok Pesantren An Nuqayah Guluk-Guluk Sumenep, Madura, (Jakarta: Pedoman Ilmu, 2001), 15 
berlaku. Belakangan pesantren yang tetap mandiri menyusun dan menerapkan kurikulum kekhasan pesantren masing-masing disebut dengan pesantren mu'adalah.

Pendidikan pesantren juga memiliki berbagai problematika yang hanya dapat diselesaikan melalui sinergitas stakeholder. ${ }^{16}$ Berbagai problematika pendidikan pesantren yang ada dapat disimpulan jawabannya yakni;

1. Dikotomi ilmu agama dan ilmu umum yang harus disudahi. ${ }^{17}$ Dikotomi dalam keilmuan hanya membuat kerancuan bagi penikmatnya. Ilmu hendaknya bebas dari berbagai pandangan selagi ia masih dapat member manfaat bagi pemburunya. Agama tidak mengenal jenis ilmu dan ilmupun tidak memandang agama, intregralisasi dari setiap jenis ilmu penting dilakukan dalam rangka kemajuan pendidikan bersama.

2. Membangun pola partifipatif dalam proses pembelajaran antara ustadz dan santir dan menyudahi paradigma dikotomi. ${ }^{18}$ Santri diberi ruang untuk lebih inovatif, optimis, kritis dan logis dalam setiap keadaan dan sikap. Ustadz hendaknya dapat membuka ruang diskusi agar kebenaran tidak selalu absolute berada pada tangannya. Perkembangan pemikiran santri harus dikedepankan oleh ustadz agar tumbuh pemikir-pemikir yang dapat mengikuti perkembangan zaman yang dinamis dan berkemajuan.

3. Peningkatan profesionalisme ustad $₹$ (pendidik) pada bidang pedagogik dan kompetensi dasar yang harus dimiliki seorang ustad $z^{19}$ Peningkatan profesionalisme ini diharapkan dapat meningkatkan kualitas guru ketika menyampaikan kajiannya. Sehingga kualitas pesantren dapat dirasakan perkembangannya yang bermula pada peningkatan kualitas para ustad\%: Masih banyak pesantren yang mengangkat santri lulusannya menjadi ustadz pengampu kajian di Madrasahnya belajar. Kesiapan mental dan kemampuan santri menjadi seorang ustad₹ dipertanyakan, apakah memang benar-benar siap atau dipaksa untuk siap? Banyak hal yang perlu diperhatikan jika hal ini terus dilakukan, minimal adanya orientasi akan kesiapan mental sebab kondisi sosial yang berubah drastis.

4. Perlunya peningkatan kualitas dan mutu pesantren (lembaga) dari berbagai aspek agar harapan masyarakat dapat terpenuhi dan menghasilkan sumber daya manusia yang berkualitas sesuai dengan tuntutan zaman. ${ }^{20}$ Pesantren harus dapat menyeimbangkan antara pendidikan formal dan pendidikan Diniyah. Tidak hanya mengutamakan pendidikan formalnya, tetapi harus dapat seimbang. Sebab kehidupan diera milenial ini tidak hanya membutuhkan santri yang pandai mengaji

16 A. Mardjun, Tantangan Pendidikan Islam Abad 21. Jurnal Hanafa, IV(1), 2007, 28

17 Abu Darda, Integrasi Ilmu dan Agama: Perkembangan Konseptual di Indonesia, Jurnal At-Ta'dib, 2015, Vol 10 (10), 10

18 Ahmad Mardjun, Tantangan .................., 25

${ }^{19}$ N. F. Natsir, Peningkatan Kualitas Guru dalam Perspektif Pendidikan Islam.(Jakarta: 2007) 8.

${ }^{20}$ Ibid, 6. 
saja, tapi juga harus disertai dengan beberapa keahlian dan kemahiran disuatu bidang untuk bekal terjun di masyarakat kehidupan nyata.

5. Beberapa pesantren masih menutup diri dari kemajuan teknologi. ${ }^{21}$ Pesantren yang beranggapan bahwa kemajuan teknologi bagi santri belum saatnya dilakukan, hal ini tampak dai tentangan keras pada penggunaan teknologi terbarukan seperti komputer, laptop, internet dan lainnya bagi para santrinya. Padahal, pada kenyataannya generasi z saat ini sangat dibutuhkan untuk melek teknologi. Media, model dan metode pembelajaran dapat dipadukan dengan teknologi agar lebih menarik.

6. Citra bebepara pesantren yang masih terkesan kumuh. Pesantren sebagai institusi pengimplementasian nilai-nilai Islam seharusnya dapat menjawab ini dengan tindak nyata. Kebersihan adalah sebagian dari imanmerupakan selogan yang selalu digaungkan kepada santri untuk cinta kebersihan disetiap keadaannya. Nyata, tantangan ini masih belum bisa dijawab dengan baik oleh beberapa pesantren. Kesan itu masih melekat dan menjadi citra yang buruk bagi pesantren itu sendiri.

Sehingga pesantren yang pada saat ini harus mampu mengikuti arus perkembangan yang sangat luar biasa. Perlu kiranya memperhatikan kurikulum, sarana dan prasarana pesantren, manajemen pesantren yang tanpa meninggalkan pendidikan formal serta unsur dasar pendidikan yang dibutuhkan. Kebutuhan absolut akan perhatian Kyai sebagai figur utama pesantren yang menjadi pembeda dari lembaga pendidikan lainnya perlu dipertahankan dan dilestarikan.

\section{Catatan Akhir}

Pesantren adalah lembaga tertua di Indonesia yang semakin hari pada seharusnya semakin berkembang. Pemerataan perkembangan pesantren diseluruh Indonesia mendapatkan perhatian penting sebab secara kualitas dan keteguhan dalam pelaksanaannya sangat mengakar sebab usia lembaganya memiliki karakter yang sangat kuat. Sehingga, perlu pesantren tidak terlena akan tuanya lembaga tersebut dan atau bahkan perlu ada catatan-catatan dalam hal anti dikotomi keilmuan, artinya pesantren tidak boleh menutup mata akan lompatan perkembangan zaman yang semakin meningkat. Juga mengingat output santri yang akan menghadapi duni aluar.

Pola pendidikan yang partisipasi aktif perlu dijadikan sebagai karakter khusus yang harus dimiliki pesantren sebagai pergeseran sistem dari doktrinasi menuju demokratisasi pesantren. Peningkatan profesionalisme asatidz sebagaimana kompetensi pendidik pada umumnya menjadi terobosan baru serta system pendidikan formal dan non formal menjadi balancing sebagai pengakuan atas pemerintah dengan memperhatikan mutu lembaga pendidikan serta peran Kyai sebagai pemegang kekuasaan penuh juga perlu memberikan perhatian penuh.

${ }^{21}$ Ibid, 9. 


\section{Daftar Rujukan}

As-Suyuthi, Jalaludin. 2005. Al-Asybah wa An-Nadzoir. Jakarta: Darul Kutub Ilmiah. Darajat, Zakiah. 2006. Pendidikan Islam dalam Keluarga dan Sekolah. Jakarta: Ruhama.

Darda, Abu. 2015. Integrasi Ilmu dan Agama: Perkembangan Konseptual di Indonesia. Jurnal At-Ta'dib. Vol 10 (01).

Ghazali, M. B. 2001. Pendidikan Pesantren Berwawasan Lingkungan: Kasus Pondok Pesantren An Nuqayah Guluk-Guluk Sumenep, Madura. Jakarta: Pedoman Ilmu.

Iryana, Wahyu. 2015. Tantangan Pesantren Salaf di Era Modern, Al-Murabbi, Vol. 2 (01).

Mardjun, A. 2007. Tantangan Pendidikan Islam abad 21. Jurnal Hanafa, IV (01).

Natsir, N. F. 2007. Peningkatan Kualitas Guru dalam Perspektif Pendidikan Islam. Educationist. Indonesia. Jurnal At-Ta'dib.

Rahardjo, M. 2006. Ed. Quo Vadis Pendidikan Islam: Membaca Realitas Pendidikan Islam, Sosial dan Keagamaan. UIN Malang Press.

Rofieq, Ainur, 2004. Profil Umum Beberapa Aspek Pendidikan Formal yang diselenggarakan Pesantren se-Karesidenan Malang dalam Mendongkrak Mutu Pendidikan Malang. FKIP Universitas Muhammadiyah Malang.

Samsudin. 2019. Integrasi Tri Pusat Pendidikan dalam Pendidikan Agama Islam. AlMurabbi: Jurnal Studi Kependidikan dan Keislaman. Vol. 5 (02).

Suyudi. 2014. Filsafat Pendidikan Islam dalam Kajian Filosofis dan Pemikiran Pendidikan Islam. Yogyakarta: Belukar.

Tafsir, A. 2005. Ilmu Pendidikan Dalam Perspektif Islam. Bandung: Remaja Rosdakarya. 